\title{
A memória dos velhos e a valorização da tradição na literatura africana: algumas leituras
}

\author{
Lidiane Alves do Nascimento* \\ Marilúcia Mendes Ramos**
}

\begin{abstract}
Resumo
Este texto pretende refletir sobre a representação literária da função social do velho na literatura africana, como guardião da memória e da tradição, ao conservar o passado, interligando-o ao presente, no que respeita à tradição dos conhecimentos aos pósteros e à contribuição que esta significa na formação identitária dos mais novos. Para tanto, faremos uma leitura dos contos africanos, a saber: Kahitu, Manga Verde e sal também, dos angolanos Uanhenga Xitu e Ondjaki, respectivamente, e Nas águas do tempo, do moçambicano Mia Couto.
\end{abstract}

Palavras-chave

Tradição. Memória. África. Literatura.

\section{Primeiras considerações sobre a memória}

Ao remetermos à abordagem da memória em nosso estudo, temos em mira que as pesquisas concernentes a esta temática recorrente no interesse de historiadores e estudiosos da literatura tornam-se relevantes à medida que buscam investigar aspectos da cultura popular, da vida em comunidade, sublinhando ainda a identidade de um povo, ao atentar para seus costumes, religiosidade, tradições, enfim, nuanças que dizem respeito à constituição social da memória.

Percorrendo o passado e os meandros da valorização da memória para a constituição da história e da identidade de um povo, podemos reportar às civilizações antigas para entender a origem da história atrelada aos mitos. O terreno sobre o qual

* Doutoranda em Letras e Linguística, área de Estudos Literários, pela Universidade Federal de Goiás. E-mail: lannasto@gmail.com.

** Professora Associada Faculdade de Letras da Universidade Federal de Goiás. Doutora em Letras (Estudos Comparados de Literatura de Língua Portuguesa) pela Universidade de São Paulo. E-mail: marilucia_ramos@uol.com.br. 
a história inicia seu trabalho perscrutador será, assim, sistematizado pelo aspecto mítico, sendo os mitos fornecedores de respostas para todas as perguntas, esclarecedores daquilo que no passado não pareceu compreensível. Ocorre que os relatos míticos emergidos com a tradição, fundada em aspectos religiosos, em costumes muito antigos, fornecem, há tempos, subsídios indispensáveis para se compreender o que caracteriza, dá forma e garante o funcionamento a uma sociedade.

É sabido que os mitos, as crenças, matizados por acervo religioso, histórico e, muita vez, imaginário, eram transmitidos via oralidade, ratificando, desta feita, o estabelecimento de uma tradição. A perpetuação desta, sua presentificação e/ou cristalização no imaginário coletivo, divulgada através da oralidade, encontrará, pois, veículo poderoso nos textos literários, asseverando a estreita relação entre história e literatura.

As narrativas orais, ouvidas dos velhos ${ }^{1}$, não podem ser percebidas como invenções particulares, uma vez que mesmo se configurando como histórias pessoais, são influenciadas, indubitavelmente, pela voz narradora, seu meio de interação, suas ordens morais, sociais e outros aspectos que tais. É lícito dizer que, pelo exercício de contar e recontar histórias sustenta-se a ciência do sujeito sobre si mesmo e sobre os outros com os quais interage em comunidade. Nesse sentido, Walter Benjamin (1980) entenderá a narrativa como transmissão de experiências entre gerações, consoante o movimento coletivo de tradições, ao relacionar fatos narrados com fatos vivenciados, não sendo possível conceber narrativa alijada da ideia de memória. O narrador, incumbido do trabalho de rememorar, ainda que nos relate histórias marcadas por visões de mundo próprias e peculiares, transcende a memória individual, sendo a memória sempre coletiva e, portanto, social, formada, como se quer reiterar, na esteira do grupo a que pertence.

Um dos maiores estudiosos da memória, Halbwachs (2006) impulsiona o seu caráter social, as referências exteriores, como a mola propulsora na acepção do tema. Para ele, não sendo inteiramente isolada e fechada, a memória individual provê o conhecimento da memória coletiva, tendo em vista que "para evocar o próprio passado, em geral, a pessoa precisa recorrer às lembranças de outras, e se transporta a pontos de referência que existem fora de si, determinados pela sociedade" (HALBWACHS, 2006, p. 72).

$\mathrm{Na}$ evocação do depoimento da testemunha e do contexto referencial sobre o qual transitam o grupo e o indivíduo que o atesta, como forma de reconstruir o que se chama memória, Halbwachs (2006) tratou de distinguir entre "memória histórica" e "memória coletiva", entendendo a primeira como reconstrutora dos elementos do presente da vida social e projetada sobre o passado reinventado, ao passo que a segunda cumpriria recompor magicamente o passado.

Acredita-se, no liame deste pensamento que corrobora a memória coletiva, que o ato de recordar é algo que se realiza em sociedade, pela presença ou evocação, no chamamento a outros e a suas obras. É preciso ressaltar, entrementes, que mesmo

\footnotetext{
1 As palavras "velho" e "mais-velho" são usadas neste artigo, que discute a memória e sua preservação, como sinônimas na maioria das vezes, mas esclarecemos que na acepção africana "mais-velho" não diz respeito a idade, mas somente a acúmulo de conhecimento.
} 
sob as bases de uma comunidade, são os indivíduos que se lembram e essa memória individual representará um, entre muitos pontos de vista possíveis acerca da memória coletiva. Nossas lembranças mais pessoais não podem prescindir da ambiência coletiva onde estamos inseridos e, portanto, influenciados pelas suas transformações. Inferimos que a memória individual, não podendo se engendrar isoladamente, se coaduna às lembranças de outros, na interação diária com o grupo, em conversas e leituras que ajudam a interligar memória pessoal e memória social.

Em sua obra, ao propor uma distinção entre memória coletiva e história, Halbwachs (2006, p. 100) lembra que a história procura compilar os fatos que ocuparam lugar na memória dos homens, selecionando-os em manuais didáticos que utilizamos nas escolas, os que atendem às regras "que não se impunham aos círculos dos homens que por muito tempo foram seu repositório vivo". A existência da memória estaria, pois, condicionada à sensação de que ela remonta às lembranças de um momento contínuo, de uma continuidade que a história intenta restabelecer, ao erigir uma ponte entre passado e presente. Mas, só a memória coletiva seria capaz de promover verdadeiramente essa continuidade, por não reter "do passado senão o que ainda está vivo ou é incapaz de viver na consciência do grupo que o mantém" (HALBWACHS, 2006, p. 102). Na memória, presente e passado não se alijam tal como dois períodos históricos distintos.

Ecléa Bosi (2004), em seu importante estudo Memória e sociedade: lembranças de velhos, ao remeter à função social do velho de rememorar, aconselhar, como um elo entre o passado e o porvir, reclama o estilhaçamento da lembrança na sociedade capitalista, que se utiliza do velho apenas no que tange à sua força servil. $O$ fato é que a sociedade moderna capitalista, ao oprimir a velhice, suplanta os apoios da memória, dando relevo à história oficial em detrimento da lembrança.

$\mathrm{Na}$ esteira de Halbwachs, Bosi (2004) reitera a ideia de memória individual sintonizada com os grupos sociais: família, escola, Igreja, os quais ajudam a delinear as lembranças que figurarão como referências do sujeito. A autora, ao perscrutar um estudo da memória, levando em conta a inserção dos fatores sociais, opta por direcionar seu trabalho às lembranças das pessoas idosas, dado que elas já tiveram a experiência de percorrer toda uma sociedade, com todas as suas marcas e características que tais.

Versando sobre as lembranças dos velhos, depreende-se que eles, na função de rememorar, não se encontram furtivos em sonhos que servem para apartá-los da vida cotidiana e seus ofícios, mas estão ocupados com o seu próprio passado de modo consciente, trazendo à tona o que dá contorno a sua vida. Não é o que acontece com o sujeito adulto ativo, que se entretece com a vida presente e suas muitas exigências, sem tempo para se delongar em lembranças passadas, as quais, quando aparecem, figuram como sonhos, lazer, atividade contemplativa.

Como vimos, a atividade de rememorar perpassa pela função social do sujeito que, no presente, reconstrói os fatos passados. Tal função será exercida quando este sujeito, antes ativo na sociedade de que faz parte, deixa de "contribuir" para o presente coletivo, alcançando o momento da velhice social que faz restar a ele apenas o encargo de lembrar, tornando-se a memória do grupo a que pertence. É a memória, 
nos dizeres de Pollak (1989), que, ao definir o que é comum ao grupo e o que o diferencia, irá fundamentar e reforçar sentimentos de pertencimento.

Com os velhos é que se pode promover a continuidade da cultura e da educação da gente adulta do presente e dos pósteros, das gerações futuras, pois permitem, em sua experiência, reviver o que já passou, como as histórias e tradições de um tempo ido, mas que permanecem, de alguma maneira, nos rastros de suas lembranças partilhadas, "pois deles ainda ficou alguma coisa em nosso hábito de sorrir, de andar. Não se deixam para trás essas coisas, como desnecessárias" (BOSI, 2004, p. 74).

Afora os malefícios e opressões que caíram sobre os velhos, com a sociedade industrial, abandonando-os ao esquecimento, é preciso ter em mira que, em sociedades outras, muito antigas, onde os costumes, modos de viver, não se contaminaram pela hegemonia do individualismo, o velho é tido como o maior bem social daquele povo.

Em outros casos, temos no oriente um exemplo de sociedade antiga, porém não concebida como primitiva, na qual se observa este tipo de transmissão de conhecimentos dos mais-velhos aos mais novos. Podemos lembrar o respeito que os japoneses dispensam a seus velhos, sinônimo de elo entre o passado e o presente, tanto que, não raro, as crianças são confiadas aos avós para receberem os conhecimentos do passado, assim como seus pais receberam de seus avós na infância. Tal ligação é garantia de manutenção das tradições mesmo em uma das sociedades mais modernas da atualidade. O lugar de honra e privilégio do mais-velho desvela aí a beleza daquele que tem o poder de iniciar uma obra a que, certamente, será continuada por seus descendentes.

No exemplo dos povos africanos, como discutiremos mais detidamente no tópico seguinte, o ancião cumprirá "a religiosa função de unir o começo ao fim, de tranqüilizar as águas revoltas do presente alargando suas margens" (BOSI, 2004, p. 82). Guardião do tesouro espiritual e das tradições da comunidade, pelo velho uma diversidade de conhecimentos chega aos mais novos, corroborando a força de sua experiência e de sua memória.

\section{A memória dos velhos e a valorização da tradição na literatura africana.}

Doravante, sem perder de vista a discussão da memória e da tradição como aspectos constituintes da identidade de um povo, centralizaremos o contexto da cultura africana, fazendo um breve preâmbulo pela história da literatura de África, ressaltando-se de antemão que, por meio do veículo cultural poderoso que representa a literatura, imprime-se a resistência destes povos, em manter sua cultura, suas tradições e sua memória, a despeito dos efeitos despóticos e irreversíveis da colonização.

Emergidos no cenário de uma sociedade onde há muito a cultura escrita mantém sua hegemonia, esquecemo-nos, muita vez, de que há sociedades originalmente ágrafas que até bem pouco tempo valiam-se exclusivamente da palavra oral para se 
comunicarem. África se nos apresenta como uma dessas nações cuja imensa valorização da tradição oral encontrará nos chamados griotes, os seus mais notáveis representantes, guardiões da memória e responsáveis pela transmissão dos conhecimentos aos mais novos.

Malgrado a modernidade ter assinalado a hegemonia do racionalismo, evidenciando, assim, o culto à experiência individual, a que traz em seu bojo aspectos como o prestígio da cultura escrita, a oralidade procura resistir, assegurando seu lugar de importância nos falares antigos dos contadores de histórias, os griotes, que se nos apresentam como "memória viva" ao recuperarem narrativas que cumprem o papel de transmitir saberes antigos que povoam a sociedade africana e ajudam, ainda hoje, pelos fios da continuidade, a tecer o curso da história.

A valorização da tradição oral, na África, longe de significar apenas um meio de comunicação, reluz uma maneira de preservar a sabedoria da ancestralidade. Nesse sentido, a palavra transmitida na oralidade conduz a herança ancestral tão valorizada por esta cultura. Os seus griotes relatam as histórias ouvidas de seus antepassados, que por sua vez, deverão ser ouvidas entres as gerações seguintes.

Ao nos determos na literatura africana, mais especificamente, voltados para Angola e Moçambique, consideramos pertinente passar em revista alguns aspectos gerais que nos permitem compreender melhor a história e a importância dessas literaturas para se fazer conhecer as culturas e as tradições dos países supracitados.

Manuel Ferreira (1977) situa a origem da literatura africana de expressão portuguesa no contexto do século $X V$, período em que se edifica ao nível de ciência e das grandes literaturas europeias, dado o esforço de cronistas, poetas, historiadores, pensadores, missionários, entre outros que ajudaram a delinear uma literatura feita por portugueses no período renascentista, a que chamamos de literatura de Descobertas e Expansão. Nascida sob o berço cristão e as políticas de dominação, tal literatura prescindiria, pois, da literatura africana de expressão portuguesa, uma vez que, historicamente, é somente a partir da criação e do desenvolvimento do ensino oficial, da liberdade de expressão e instalação do prelo, datados dos anos 40 do século XIX, que emerge, na África, uma atividade cultural regular.

Ao trazermos à tona a discussão sobre as bases da história dos povos africanos, importa salientar que séculos de colonialismo culminaram na destruição de traços culturais e na interdição dos contatos entre as gentes que habitavam o continente. Em Angola e Moçambique, a exemplo, desde o início de suas atividades literárias, no século XIX, aos dias atuais, a literatura "carrega o peso das contradições sobre as quais se estruturava a sociedade colonial e suas repercussões no período que sucede à independência política conquistada nos anos 1970" (CHAVES, 2005, p. 250).

Uma dessas contradições, consoante as acepções de Chaves (2005), seria a escolha da língua portuguesa como instrumento de expressão, mais especificamente, o problema da escrita, que no contexto de uma sociedade hierarquizada tornou-se elemento de distinção, uma vez que o seu domínio fez-se essencial na instituição do perfil social. Desde o século XIX, em Angola, a escrita tornou-se promovedora de uma linha fronteiriça entre a civilização e a barbárie. Doravante, intensificou-se o abismo 
entre a tradição oral e o código da escrita no papel de formulação e transmissão de conhecimento.

Situados à margem e interditados em seus direitos, os moçambicanos, dominando o código identificado com a civilização, farão da escrita um veículo propício para denunciar sua situação injustificada e injustamente marginalizada. Enquanto em Angola as propostas da Geração de Mensagem são buscadas no afã de revigorar as raízes atingidas pela cisão, concomitantemente, em Moçambique, a voz de um José Craveirinha põe-se a anunciar que sua africanidade não excluiria o lado paterno, pois, sendo ele um português do Algarve, ao trazer em seu sangue marcas de muitas misturas acredita, como muitos outros poetas, que em um contexto liberto da hierarquização das diferenças as trocas e as mesclagens acarretariam um rico processo de formação das identidades.

Não obstante a consciência da importância de se noticiar o patrimônio de uma literatura escrita, Santilli (1985), ao realizar um percurso pela literatura tradicional, ressalta que as nações de Angola, Cabo Verde e Moçambique eram originalmente ágrafas, tendo cultivado por tempos imemoriais uma literatura oral. À luz dos estudos de Héli Chatelain, missionário suíço que chegara a Angola em 1885, a pesquisadora elenca, didaticamente, seis categorias da literatura oral levantadas por Chatelain para fins de estudo da literatura oral africana. A primeira, de estórias de ficção; a segunda, de estórias verdadeiras ou tidas como orais; a terceira classe, das malunda, nas quais os efeitos de nação ou tribo eram transmitidos entre velhos e anciões; a quarta classe, composta de provérbios que sintetizam estórias; e, ainda, a quinta e sexta classes, da poesia e música, com estilos variados, desde o épico e o dramático; das adivinhas que entreteciam e incitavam a memória.

Tais elementos concorrem para indicar um patrimônio oral a ser recuperado nessas nações, embora o atestado de uma literatura oral, por si só, consiga demolir o pensamento, já descartado, na atualidade, de que as sociedades africanas seriam estáticas, não passíveis de evolução. A esse propósito, na fortuna literária de Angola, a situação de angústia dos negros é contemplada por escritores como Fernando Monteiro de Castro Soromenho, que teriam aderido à causa dos oprimidos, erigindo suas narrativas a partir das experiências de convívio e aprendizado advindos do sertão angolano. Paralelamente, no caso de Moçambique, a penetração da cultura portuguesa manteve-se insignificante por um longo tempo, sendo a maioria da população analfabeta e permanente em suas práticas tradicionais, no que concerne ao uso da transmissão oral.

Ao longo de sua trajetória, os estudos das Literaturas Africanas eram fortemente matizados pelas questões referentes à busca da identidade nacional, característica que reflete a resistência pelas cisões provocadas pelo regime opressor colonialista, vigorando por longo tempo. Hoje, as questões que envolvem o tema da identidade foram relativizadas, sem com isso, saírem da pauta. A preocupação com a identidade dos povos africanos emerge na literatura moderna, nas narrativas de escritores que recorrem às contribuições de provérbios, ritmos, símbolos das religiosidades e costumes africanos, que, infelizmente foram, em muito, silenciados pela colonização portuguesa, que impôs sua cultura e sua religião. 
Nessa realidade em que a presença colonialista promove entraves e pretende silenciar pela força coerciva, a oralidade, o contar histórias e o exercício de rememorar se afiguram como modos de se conservar e transmitir os conhecimentos e valores dessas sociedades. Entre os africanos, tradicionalmente, a palavra oral é veículo sagrado de seus ritos, religiosidades e costumes. Por exemplo, escritores angolanos que despontaram nos anos de 50 e 60, amalgamaram a palavra oralizada com a escrita, como forma de (re)inventar maneiras de se contar histórias, preservando, por sua vez, a vida cultural coletiva de sua nação.

As narrativas que mesclam oralidade com técnicas exclusivas de escrita, além de informarem ensinamentos próprios daquela cultura, muita vez se encarregaram de denunciar os efeitos dilacerantes do colonialismo, cuidando para que não se perca o que restou dos costumes e tradições locais. Na cultura angolana ancestral, sabe-se que narrar é atribuição dos velhos, os mais especializados na sabedoria de contar histórias, dar conselhos e partilhar experiências. Assim, textos literários refletirão esse costume tradicional, configurando narrativas que pontuam a presença do velho como imprescindível na conservação da memória coletiva. Nessa sociedade, a autoridade dos griotes e outros elementos integrantes do mundo angolano que buscam revisitar práticas ancestrais, tais como o diálogo coletivo, muitas vezes, concretizado em volta da fogueira, corroboram, no âmbito da literatura, a necessidade de reverenciar os aspectos identitários que determinam a cultura.

No contexto moçambicano, assim como ocorre em boa parte do continente africano, as tradições vivem e se expressam no respeito aos mais-velhos, na importância atribuída à palavra falada, no costume de contar histórias e valorizar elementos da natureza, na reverência aos antepassados e demais elementos que identificam a formação de África. Observa-se que no período da independência de Moçambique, ocorrida em 1975, as manifestações literárias do país convocam a reflexão sobre o pós-guerra, o cenário modifica-se, sem, contudo, deixar de lado as questões relativas à tradição. A literatura não é mais unicamente um suporte de ações denunciadoras, mas quer cumprir também o papel de resistência à imposição cultural europeia.

Nessa perspectiva, a memória deixa de ser um elemento natural humano, sobrevivente em si mesma em forma de lembranças, para efetivar um meio de transmitir às gerações posteriores o passado de uma comunidade ou nação. Rememorar os mitos e histórias pelo registro da literatura torna-se um modo eficaz de resistir ao processo massificador da modernização e à assimilação cultural que podem, coercitivamente, afastar os povos de seus costumes e origem, porém, sem conseguir suplantar as marcas impressas pela memória.

\section{A presença dos velhos em contos de Angola e Moçambique: algumas leituras}

Pautados na assertiva de que o ato de narrar e contar histórias caracteriza o elo geracional e mantenedor das tradições, costumes e hábitos sociais que irá colaborar na perenização da memória coletiva, abordaremos, no presente tópico deste estudo, a 
representação do velho nos contos "Vozes na sanzala (Kahitu)", de Uanhenga Xitu, "Manga verde e o sal também", de Ondjaki, e "Nas águas do tempo", de Mia Couto como elemento fundamental nesse processo em que a memória exerce a função social de contribuir na manutenção das tradições do povo africano.

Não sem razão, o lugar do velho na sociedade africana é corroborado como um espaço de privilégio, uma vez que ele concretiza a junção entre narrativa e vida, metaforizando um elo a interligar as diferentes gerações e desmitificar a separação entre espaços e tempos. Ao promover a diluição das fronteiras entre espaços e tempos, o velho enceta momentos de interações e trocas de experiências que veiculam saberes, os quais, uma vez aprendidos pelos mais novos, não se perderão, atestando, como vimos, a importância do papel de transmitir o tradicional, para que este não seja diluído pelos conhecimentos aclamados pela sociedade moderna.

Do que foi dito anteriormente acerca das literaturas de Angola e Moçambique, quer-se reiterar que ambas as nações têm suas histórias marcadas pela repressão empreendida pela força hostil do colonialismo. Em Angola, a longevidade do período colonial, propiciou uma literatura inicialmente pouco criativa, na concepção dos críticos especializados, dada a precária escolarização, não apta a viabilizar uma literatura atuante, quadro modificado apenas em fins da década de 40, com o lançamento em Luanda, do brado "Vamos descobrir Angola". Já em Moçambique, entrementes, a favorável localização geográfica, a estabelecer fronteiras com muitos outros povos africanos, contribuiu para que se engendrasse, desde a década de 40 , uma literatura fértil, marcada por grande quantidade de publicações.

Enfatizamos ainda que, nas comunidades de Angola e Moçambique, fortemente marcadas por traços da oralidade, configurando a força dessas culturas, a escrita literária, ao nutrir-se de recursos orais, o faz no afã de memorizar, lembrar a história local, fixando modos de expressar e pensar seus costumes, suas tradições.

No que diz respeito ao conto, no período pós-colonial, este tem se configurado como um importante gênero literário, ao ganhar destaque no que tange à fixação da cultura oral africana e ao resgate da arte de contar histórias como mantenedora das tradições ancestrais. Sob a ameaça da supremacia da cultura escrita, os contos simbolizam uma forma de resistir ao abandono das tradições concernentes ao seio familiar, ao perpetuar ensinamentos fundamentais sobre a história, a cultura, os valores sociais que dizem e dão sentido à sociedade. Nos complexos contextos de Angola e Moçambique, o conto configura-se como gênero apropriado ao "contar histórias", porquanto se mostra adaptável e acessível. Muitos contos têm como motivo a figura do contador de histórias, o griot, a simbolizar a presença da oralidade. $\mathrm{Na}$ literatura, a retomada desses narradores, contadores tradicionais de história, revigora, pois, no texto escrito, a relevância de se manterem vivas as belas histórias orais. Em um contexto de opressões, guerras e lutas pela independência, a literatura africana assumiu o projeto de reafirmar identidades essenciais em defesa da nacionalidade. Para Fonseca (2003, p. 63): 
as literaturas africanas de expressão portuguesa desenvolveram mecanismos para recuperar uma tradição que fora sufocada pelo colonialismo. Entre eles, identificase a acentuada tendência de retomarem as representações do velho, o guardador da memória do povo, e com ela compreender peculiaridades da cultura ancestral evidenciada em projetos de nação e de nacionalidade, assumidos como plataforma das lutas pela independência, nos espaços africanos de língua portuguesa.

Em "Vozes na sanzala (Kahitu)", do escritor angolano Uanhenga Xitu (Agostinho André Mendes de Carvalho), de 1976, encontraremos um cenário que retrata o contexto de uma sociedade recém-independente, mas que, marcada pelas ações colonizadoras, precisa recuperar os seus valores e restituir sua identidade. A literatura será, dessa forma, instrumento divulgador dos valores identitários angolanos. É o que averiguaremos com Kahitu, acerca do tratamento discursivo, por exemplo, em que os termos próprios das línguas angolanas são mesclados à língua portuguesa.

Kahitu é personagem central do conto, sendo apresentado aos poucos a se tornar um sábio, mais-velho e cada vez mais experiente, portador de muitos conhecimentos, porém, causará desequilíbrio na sanzala, porque o seu comportamento desvia-se do exemplar. Ramos (1996) reporta-nos que a ênfase nos espaços rurais de Angola, como se nota em Kahitu, casa-se com o ensejo de se preservar as tradições orais, dando continuidade às práticas tradicionais, o que se torna mais difícil nos meios urbanos que tendem ao cosmopolitismo.

Atrelado aos valores tradicionais africanos, o narrador, já no início do conto, revela preocupação em estabelecer a ordem (origem) dos fatos narrados, uma vez que, nas histórias africanas, tudo tem uma explicação dada pelas tradições e costumes do povo pautados em valores ancestrais. A recuperação desses valores transmitidos pela tradição oral já surge, inicialmente, com a necessidade de se explicar a origem de Kahitu, os fatos que antecedem o seu nascimento e o justificam. Kahitu nasce paralítico, embora dotado de muita inteligência e sua situação se explica pelas crenças tradicionais africanas. Ocorre que o não cumprimento de um ritual às divindades que salvaram a vida de sua avó, por parte de seu pai e denunciado na fala da mãe, redundou na sua deficiência física:

[...] Mas quando fiquei no estado de Kahitu perguntei-te se tinham ido ao Kilamba. Respondeste que sim. Mas não o fizeste. Enganaste-me. E enganaste-te a ti próprio. Porque tu sofres tanto como eu ou mais, desde que se manifestou a doença de Kituta no Kahitu (XITU, 1976, p. 37).

Percebe-se aí a presença suprema das divindades, as que irão cobrar, em forma de punição, a não realização do que é esperado.

Num lugar onde se impõe de muitas formas a presença do colonizador, Kahitu cresce à margem, sendo privado a certa altura de frequentar a escola e as demais situações oficiais. No entanto, seu estado marginal não o exime de acumular muitos conhecimentos. Ele consegue aprender a língua do colonizador, adquirir habilidades como a do ofício de ferreiro, ampliar força física e sua inteligência, uma vez que tendo tempo para ouvir as histórias dos antepassados, torna-se o experiente "narrador", dotado de suficiente sabedoria para resolver as demandas das pessoas de sua 
comunidade. O conhecimento da língua e da cultura do seu povo, e ainda da língua portuguesa, faz com que ele transite entre as duas culturas, atuando em favor dos seus junto ao colonizador ou tornando-se o velho sábio que até criará uma Escola de Civismo, disposto a ensinar meninos e meninas.

Sabedor então de muitos ofícios, Kahitu, representando a figura do mais-velho, passa a ser bastante respeitado entre os seus, como mestre conselheiro, a quem "foi dado abranger uma vida inteira. Seu talento de narrar lhe vem da experiência; sua lição, ele extraiu da própria dor; sua dignidade é a de contá-la até o fim, sem medo" (BOSI, 2004, p. 91). Assim é que a vida de Kahitu, circundada por uma atmosfera sagrada e consequentemente atingida pela exclusão, adquire importância e finalidade:

\begin{abstract}
O mestre era o homem mais informado da sanzala. Estava a par de todas as conversas, até das íntimas. Conhecia a fundo o segredo de algumas famílias. Porque, enquanto os seus contemporâneos faziam da sanzala lugar de transição, ele estava lá desde a nascença. Viu velhos e novos morrerem, e crianças a nascerem. Assistiu a casamentos e divórcios. Conhecia todo o verbo e adágios regionais para conquistar mulheres. Também saiba derrubar um argumentador astucioso. E servia como orientador de muitos rapazes para conquistarem moças, e conselheiro de moças para se escaparem de rapazes com más intenções (XITU, 1976, p. 61).
\end{abstract}

A esse respeito, Ramos (1996) assevera que as contribuições de Kahitu na sanzala aludem aos conhecimentos dos griotes, mestres tradicionalistas da África Ocidental, lembrando que ele exerceria as funções do griot ao ser capaz de resolver uma série de questões concernentes à sanzala. Ao mais-velho, conhecedor das tradições, reitera-se que, caberia mediar, nas situações de desequilíbrio, "resgatando do passado toda a sabedoria para restabelecer a harmonia, sendo a sua palavra ouvida e respeitada [...]" (RAMOS, 1996, p. 34).

Não obstante, ao mostrar-se conhecedor da arte da sedução, Kahitu incorre no erro de usar do saber para proveito próprio, seduzindo Saki, moça bonita e muito desejada, em sua comunidade. Saki engravida após ser envolvida por Kahitu e, nesse episódio, mais uma vez é na fala dos mais-velhos que está a revelação da verdade. Uma idosa mulher de Kisoko é quem descobre e denuncia a gravidez. No desencadeamento dessa ação, o erro de Kahitu o submete à imposição do julgamento, não cumprido por fim, devido à condenação antecipada que ele impõe a si mesmo ao cometer suicídio. A morte de Kahitu acarretará também consequências desastrosas para sua comunidade, que exageradamente o condenará, assim como as divindades, que se vingam por meses do desequilíbrio causado por ele e pelos seus, que se beneficiaram de seus conhecimentos. Em suma, vê-se que Uanhenga Xitu, neste conto, dimensiona o poder do tempo mítico das tradições orais angolanas, ao recuperá-las, do passado para o presente de sua fiç̧ão, para que elas se revigorem, em continuidade, e não se percam no tempo.

No conto do angolano Ondjaki, escritor contemporâneo, deparamo-nos com uma literatura que conflita os ideais capitalistas edificados sobre a Angola moderna, pósindependência, e as ideologias tradicionais arraigadas à cultura do país. Falamos especificamente da obra Os da minha rua, detendo-nos no conto "Manga verde e o sal 
também", no qual, como nos demais contos dessa coletânea, a visão infantil do personagem-narrador, criança em fase de transição para outro estágio da vida (o da adolescência) que conseguirá rememorar um período lúdico e feliz, embora vivido em cenário de opressão dos tempos críticos da sociedade angolana, tentando se recuperar dos traumas da guerra.

O contexto da cidade de Luanda nas décadas de 1980 e 1990 é retomado numa mistura de memória individual do personagem (que sugere também a memória do escritor, incluindo fatos biográficos no conto) com a memória coletiva de uma sociedade também em período de importante transição histórica. A presença da criança e o seu olhar matizado de pureza dos que veem o mundo com ares de novidade, contribui, sobretudo, para uma compreensão histórica de Angola, desprovida de influências e comprometimentos, porque ousada e irreverente.

Em "Manga verde e o sal também", o autor refere-se à infância, poeticamente equiparando-a ao tempo dos sabores diferentes, dos cheiros e das lembranças que quer resgatar: "Era assim, antigamente, na casa da minha avó. No tempo da Madalena Kamussekele." (ONDJAKI, 2007, p. 79).

A alusão à casa da avó rememora, na pauta presente, o antigamente, que mesmo tangido pela fria realidade dos "trabalhadores soviéticos", não deixou dissipar, nas crianças, a fértil capacidade inventiva, o que permitia ver nas obras do mausoléu a imagem de um "foguetão". No presente conto, a memória é liricamente restituída pelo menino que se despede dos cheiros da infância, transição da vida que se pode cotejar à transição do país, também para a vida adulta.

Para Neves (2008), a perspectiva infantil adotada nos contos de Ondjaki, concomitante ao desvelamento dos sabores pueris e dos brinquedos que cercavam a infância, logra apresentar os problemas incutidos no bojo da nova sociedade que experimenta a modernização ao contemplar o mundo de forma sincera e inocente, destituída de visões cristalizadas e/ou, conforme expressões do crítico referenciado, esvaídas de qualquer ranço ideológico.

Ao relatar suas peripécias com os primos, o narrador personagem de "Manga verde e o sal também", nos contará sobre o dia em que colheram mangas verdes e persuadiram Madalena, que tomara conta da casa e dos meninos na ausência da avó, a lhes dispensarem o sal para que se deleitassem. Esse universo encantado da infância será, pois, matizado pelo sabor proibido de "manga verde com sal": "Eram risos ao fim da tarde com banda sonora dos camiões e restos de sol só possíveis de acontecer com manga verde na boca, anestesiada com o sabor salgado do sal grosso, melhor porque roubado" (ONDJAKI, 2007, p. 81).

Madalena é delatada pelo menino narrador e sofre o castigo de apanhar de cinto da avó e da tia Maria, por não ter cumprido o recomendado, atrasando o jantar, sem ter deixado a mesa pronta e com as pistas denunciadoras deixadas pelos pingos de manga no chão. Aqui, no resgate infantil da memória, insiste-se, pela autorização dos mais-velhos, personificados pela tia Maria e a avó Nhé, em manter vivas as tradições passadas, continuando-as na vivência dos mais novos, aptos a aprender. Entram em choque os antigos saberes concernentes à hora do jantar e ao que se pode comer, com a descoberta pelas crianças de novos sabores tais como o de "manga verde com 
sal", lembrando que o desapontamento da avó e da tia, frente à atitude de Madalena, reflete o fato de a memória dos antigos estar apoiada "na estabilidade espacial e na confiança em que os seres de nossa convivência não se perderiam, não se afastariam" (BOSI, 2004, p. 18), pois que valores ligados à coletividade, como a família larga, o apego a certas coisas etc., foram constituídos.

Na obra de Mia Couto, notável escritor moçambicano, as representações da memória e da identidade cultural de Moçambique são atestadas, muita vez, na figura dos velhos, mantenedor dos referenciais da nação, da memória, que cumpre especular no presente, as histórias passadas que colaborarão para delinear as histórias que incidirão no porvir. Vê-se, dessa forma, que no trabalho do autor a memória exerce relevante papel no que se refere à busca de construção da identidade cultural do país. Segundo Macedo (2008), a memória pontua como elemento fundamental na literatura de Mia Couto, a constituir interrogação necessária do presente sobre o passado e sobre o futuro, características tanto de sua obra ficcional como nos seus textos críticos.

O conto "Nas águas do tempo", de 1996, é emblemático, dentre os que abordam a figura do ancião como referencial da cultura e das tradições moçambicanas, que tentam se reconstruir após os massacrantes anos de lutas pela libertação, de guerra civil, que prejudicaram a constituição da identidade nacional. No referido texto, a coexistência do tradicional e do moderno perpassa pela relação temporal a interligar passado e presente, com ênfase à valorização das tradições que, repassadas aos mais novos, erigem uma continuidade identitária. $O$ ponto central da história é o elo entre avô e neto, o que conduz à transmissão do testemunho, enfocando a importância do aprendizado dos costumes que resistem na força da oralidade, da palavra sagrada proferida pelos mais-velhos. Através do avô, abre-se um manancial de saberes antepassados que revigoram no presente, por vias da continuidade: "[...] era ele quem me conduzia, um passo à frente de mim [...]. O avô era um homem em flagrante infância, sempre arrebatado pela novidade de viver. (COUTO, 1996, p. 9).

O neto é, pois, o narrador-personagem que conta-nos de suas idas, de canoa, com o avô, a um grande lago onde desaguava um rio, a despeito dos olhos reprovadores da mãe. $\mathrm{O}$ avô, mestre no ensinamento do que imprimia novidade, transmite ao menino as riquezas das tradições africanas, aconselhando-o ainda de que vá sempre a favor da água para não contrariar a lógica das divindades.

Mas o verdadeiro objetivo do avô no freqüente passeio era conduzir o neto para que ele aprendesse a ver os panos brancos da outra margem, conhecendo o "lugar das interditas criaturas". Tal intento se concretiza apenas quando ocorre a passagem do avô para a outra margem (o além), fazendo com que, nos olhos do menino, transpareça o que antes parecia debalde no ensinamento do avô. Assim, o neto, símbolo do "mais novo", a germinar as sementes do futuro, ao se tornar mais-velho e tendo captado a lição do avô, retorna ao lago com o filho para que ele aprenda também a ver os panos da outra margem, perpetuando no doravante, os rituais ensinados no outrora. O menino é a ponte que intermediará as gerações passadas e as futuras, ao passo que a água e a canoa simbolizam a travessia, o movimento que possibilita a passagem do plano material para o plano espiritual, deixando entrever que esses dois mundos estão sempre interligados: "[...] naquele lugar se perdia a fronteira entre água e terra." (COUTO, 1996, p. 10). 
Ademais, sublinha-se que, na cultura africana, vida e morte não se encontram separadas, havendo um elo que interliga os dois mundos (material e espiritual). 0 velho cumpre, então, serenamente, sua missão de transmitir os ensinamentos e realizar por fim sua travessia. Essa explicação mítica da morte como travessia para outra margem exprime a linha tênue entre o sobrenatural e o que é tido como natural. Aos ouvidos atentos do neto, o velho preconiza que, para enxergar melhor e compreender o insólito, o que se afigura como inexplicável, os olhos precisam estar limpos de censura, puros e livres das convenções mundanas que costumam cegar os homens. Dessa forma, cumprindo os ritos africanos, o velho difunde pela oralidade as histórias de outros precursores, urdindo um fio de continuidade, à medida que os mitos, os rituais, as histórias são recebidas e repassadas coletivamente:

O que acontece, meu filho, é que quase todos estão cegos, deixaram de ver esses outros que nos visitam. Os outros? Sim, esses que nos acenam da outra margem. $E$ assim, Ihes causamos uma total tristeza. Eu levo-Ihe lá nos pântanos para que você aprenda a ver. Não posso ser o último a ser visitado pelos panos (COUTO, 1996, p. 12).

Há, na imagem de perenidade e continuidade aventadas pelo fluxo das águas, a força da memória que se pretende resgatar para que a existência se perpetue através das vozes das gerações vindouras. Aqui, a tradição se faz presente na retomada ao passado como forma de resistência ao mundo moderno que tende a desvalorizar os costumes antigos. Pelo liame da tradição, conforme dito, repisadas vezes, constrói-se a memória social da comunidade, onde o velho e seu elo com a criança simbolizam o retorno às tradições ancestrais com vistas a impedir que elas desapareçam nas gerações futuras.

Para finalizar este tópico, convocamos, ainda uma vez, as palavras de Bosi (2004, p. 22):

O ancião não sonha quando rememora: desempenha uma função para a qual está maduro, a religiosa função de unir o começo e o fim, de tranquilizar as águas revoltas do presente alargando suas margens [...]. O vínculo com outra época, a consciência de ter suportado, compreendido muita coisa, traz para o ancião alegria e uma ocasião de mostrar sua competência. Sua vida ganha uma finalidade se encontrar ouvidos atentos, ressonância.

\section{Palavras finais}

Conservar a memória coletiva das nações africanas implica a manutenção do patrimônio das tradições orais. Os tensos processos de ruptura e descontinuidades experimentados pelas nações angolanas e moçambicanas não podem ser esquecidos, porém, sempre lembrados, refletidos, recontados, de geração a geração, juntamente à divulgação dos matizes que caracterizam a cultura e as tradições desses países. Rememorar, pois, constitui exercício demasiadamente auxiliador das interpretações do presente que se constrói paulatinamente. A releitura das crenças africanas, promovida no âmbito literário, pelos autores estudados, ao buscar luz no passado e suas origens, 
subsidiam na reconstrução das identidades das nações mencionadas. Neste intuito, o mais-velho, detentor da sabedoria que perpetua a cultura, representa aquele que tem o poder de remeter ao passado para que o presente se faça melhor entendido e o futuro melhor engendrado, elemento sagrado e fundamental na tarefa de mediar valores antigos e valores que incidem sobre a sociedade contemporânea.

\section{Referências}

BENJAMIN, Walter. O narrador. In: . Os pensadores. São Paulo: Abril Cultural, 1980.

BOSI, Ecléa. Memória e sociedade: lembranças de velhos. São Paulo: Companhia das Letras, 2004.

CHAVES, Rita. Angola e Moçambique: o lugar das diferenças nas identidades em processo. In: . Angola e Moçambique: experiência colonial e territórios literários. Cotia, SP: Ateliê editorial, 2005.

COUTO, Mia. Nas águas do tempo. In: Estórias Abensonhadas: contos. Rio de Janeiro: Nova Fronteira, 1996.

FERREIRA, Manuel. Introdução Geral. In: Literaturas Africanas de Expressão Portuguesa. Portugal: Livraria Bertrand, 1977.

FONSECA, Maria Nazareth Soares. Velho e velhice nas literaturas africanas de língua portuguesa contemporâneas. In: BARBOSA, Maria José Somerlate (Org.). Passo e Compasso: nos ritmos do envelhecer. Porto Alegre: Edipucrs, 2003.

HALBWACHS, Maurice. A memória coletiva. Trad. Beatriz Sidou. São Paulo: Centauro, 2006.

MACEDO, Tânia. A narrativa Contemporânea moçambicana. In: MACEDO, Tânia;

MAQUÊA, Vera. Literaturas de Língua Portuguesa - Marcos e Marcas - Moçambique. São Paulo: Arte \& Ciência, 2007.

NEVES, Alexandre Gomes. Os da minha rua. Ondjaki. Revista Crioula. São Paulo, Universidade de São Paulo, n. 3, maio 2008. Disponível em

<http://www.fflch.usp.br>. Acesso em 02 jan. 2011.

ONDJAKI. Manga verde e o sal também. In: Os da minha rua. Rio de Janeiro: Língua Geral, 2007.

POLLAK, Michael. Memória, esquecimento, silêncio. Trad. Dora Rocha Flaksman. Revista Estudos Históricos. Rio de Janeiro, vol. 2, n. 3, p. 3-15, 1989. Disponível em <http://virtualbib.fgv.br>. Acesso em 15 dez. 2010.

RAMOS, Marilúcia Mendes. Entre dois contares: o espaço da tradição na escrita de Uanhenga Xitu. 1996. Tese (Doutorado em Estudos Comparados de Literaturas de Língua Portuguesa) - Departamento de Letras Clássicas e Vernáculas, Universidade de São Paulo, São Paulo, 1996. 
SANTILLI, Maria Aparecida. 1. Apresentação: uma antologia de africanos brasileiros/2. Três literaturas distintas. In: . Estórias africanas: história e antologia. São Paulo: Ática, 1985.

XITU, U. Vozes na Sanzala (Kahitu). In: Mestre Tamoda e Kahitu. São Paulo: Ática, 1984 (1a. ed. em setembro de 1976, Edição do autor, Luanda).

\section{Title}

Memory of old and Appreciation of Tradition in African Literature: Some Readings.

\section{Abstract}

This paper discusses the literary representation of the social function of the elder man in African literature, as guardian of memory and tradition, to preserve the past, linking it to the present, with regard to the tradition of knowledge to future generations and the contribution that this means in identity formation of the youths. To this end, we will read African tales, namely: Kahitu, Manga verde e sal também, by Angolan writers Uanhenga Xitu and Ondjaki, respectively, and Nas águas do tempo, by Mozambican Mia Couto.

\section{Keywords}

Tradition. Memory. Africa. Literature.

Recebido em 22.09.2011. Aprovado em 28.11.2011. 